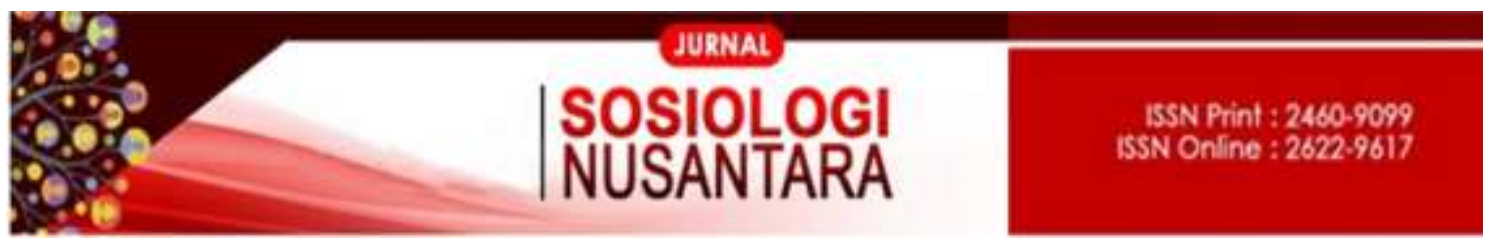

https://ejournal.unib.ac.id/index.php/jsn

DOI ://doi.org/10.33369/jsn.5.1.55-76

\title{
RELASI AGEN DAN STRUKTUR: RUANG NEGOSIASI \\ DALAM PENGELOLAAN SUMBERDAYA HUTAN DI KABUPATEN LEBONG
}

\section{RELATION OF AGENTS AND STRUCTURES: NEGOTIATION SPACES IN MANAGEMENT OF FOREST RESOURCES IN LEBONG DISTRICT}

\author{
Panji Suminar \\ soeminar1962@yahoo.com
}

Jurusan Sosiologi Fakultas Ilmu Sosial dan Ilmu Politik, Universitas Bengkulu

\begin{abstract}
Abstrak
Penelitian ini mengacu pada studi yang berkaitan dengan relasi antara agen dan struktur dalam pengelolaan hutan berbasis masyarakat dengan memasukkan kerangka teori giddens tentang strukturasi. Kajian yang dilakukan bertujuan untuk memperjelas relasi antara negara dan elite lokal dalam membuka ruang negosiasi terkait dengan pengelolaan hutan yang ada. Penelitian ini dilakukan di Desa Ladang Palembang, Kabupaten Lebong, Provinsi Bengkulu. Data dikumpulkan melalui observasi, wawancara mendalam, dan metode dokumentasi. Informan yang terlibat dalam penelitian ini adalah elite informal dan formal setempat, para pengambil keputusan tentang pengelolaan hutan, dan organisasi yang berkaitan dengan pemberdayaan masyarakat lokal. Temuan mengungkapkan bahwa hubungan antara elite lokal dan pemerintah (negara) telah mampu membuka ruang negosiasi yang berkaitan dengan pengelolaan hutan. Hubungan antara agen telah menghasilkan dan mereproduksi struktur sosial yang berkaitan dengan pengelolaan hutan. Struktur tersebut terdiri dari berbagai kelembagaan seperti nilai-nilai bersama, norma dan sanksi, nilai-nilai sosial dan etika, peraturan formal, adat istiadat, dan lain-lain. Struktur ini ditujukan untuk memenuhi berbagai kebutuhan dan kepentingan agen.
\end{abstract}

Kata Kunci : Agen, Elite Lokal, Lebong, Hutan Konservasi, Strukturasi

\section{Abstract}

This study illustrates the phenomenon of the relationship between agents and structures in community-based forest management by integrating Anthonny Giddens's thinking about structuration. The study carried out aims to clarify the relations between the state and localelites in opening negotiation spaces related to existing forest management. This research was conducted in the Ladang Palembang Village, Lebong District, Bengkulu Province. Data are collected through observation, in-depth interviews, and documentation methods. The informants involved in this study were local informal and formal elites, decision makers about forest management, and organizations related to local community empowerment. The findings reveal that the relationship between the 
Relasi Agen Dan Struktur: Ruang Negosiasi Dalam Pengelolaan Sumberdaya Hutan ......

local elite and the government (state) has been able to open up negotiation space relating to forest management. The relationship between agents has produced and reproduced social structures related to forest management. The structure consists of various institutions such as shared values, norms and sanctions, social and ethical values, formal regulations, customs, and others. This structure is intended to meet the various needs and interests of agents.

Keyword : Agents, Lebong, Local Elite, Protected Forest, Structuration.

\section{PENDAHULUAN}

Masalah pengelolaan sumberdaya hutan selalu berkait erat dengan konflik antara pemegang kekuasaan pengelolaan hutan, satu sisi, dan masyarakat lokal, disisi lainnya. Konflik-konflik tersebut seringkali tidak dapat terselesaikan dengan baik, dan bahkan intervensi negara dan masyarakat terhadap sumberdaya hutan dengan berbagai latar kepentingannya menyebabkan kerusakan hutan yang terus semakin mengkhawatirkan. Kecenderungan tersebut menggenapi premis Hardin (1968) tentang The Tragedy of the Commons yang mengilustrasikan adanya tragedi kehancuran pengelolaan sumberdaya alam bagi umat manusia. Meskipun demikian, kajian-kajian tentang konflik pengelolaan sumberdaya hutan sudah banyak terdokumentasikan dengan baik (Peluso, 1995, 2006; Suminar et al., 2004, Tangketasik, 2010). Semua kajian tersebut pada dasarnya bermuara pada ketidakseimbangan kekuasaan antara negara dan masyarakat lokal dalam pengelolaan sumberdaya hutan. Diperlukan adanya pembukaan ruang-ruang negosiasi antara pihak-pihak yang berkonflik untuk mencapai konsensus dalam pengelolaan sumberdaya hutan.

Tulisan ini memotret dinamika relasi antara agen dan struktur yang terus berkontestasi untuk memperoleh akses terhadap pengelolaan sumberdaya hutan dengan mengadopsi pemikiran Giddens tentang strukturasi yang mengilustrasikan suatu hubungan dialektika antara struktur dan agen (tindakan) yang disebut konsep dualitas struktur, atau tindakan dan struktur saling mengandaikan (Giddens 2009; 2010). Teori ini relevan diangkat untuk menganalisis simbol-simbol, gagasan, keyakinan dan norma sebagai suatu budaya yang bekerja secara strukturasi dalam praktek-praktek sosial penguasaan dan pengelolaan sumberdaya hutan antara negara dan masyarakat lokal.

Aparatur negara, elite lokal, dan berbagai individu selalu menampilkan relasi yang seringkali bersifat dinamis sesuai dengan kepentingannya masing-maisng. Kerapkali relasi tersebut berjalan dengan nuansa kolaboratif, tapi dalam situasi lain 
relasi tersebut diwarnai dengan konflik ide, gagasan, dan nilai antar pihak yang berkepentingan. Dinamika relasi agen dan struktur inilah yang justru sangat menarik untuk dianalisis karena akan melahirkan relasi-relasi kekuasaan antar pihak yang berinteraksi, dan bahkan bentuk-bentuk negosiasi baru.

Relasi dinamika agen dan struktur sendiri dipandang cukup menarik untuk dibahas dengan pertimbangan bahwa agensi dalam kehidupan sosial tidak dapat dihilangkan ataupun dihapuskan. Setiap orang dan atau kelompok dapat menjadi agen bagi suatu peran. Aparatur negara, misalnya, dapat menjadi agen dan memegang peranan penting dalam perolehan akses terhadap sumberdaya bagi semua pihak yang berkepentingan. Demikian juga, elite lokal memainkan peranannya sebagai agen untuk menyediakan pelayanan-pelayanan yang membutuhkan keterlibatan masyarakat lokal. Demikian juga tokoh-tokoh lain seperti tokoh agama, pendidikan, aktivis lingkungan, dan sebagainya. Semuanya memainkan peran sebagai agen yang memfasilitasi pihakpihak berkepentingan.

Sementara itu, struktur merupakan wujud interaksi dalam kehidupan manusia yang menghasilkan berbagai pranata ataupun institusi seperti nilai bersama (shared values), norma dan sanksi, arena sosial, dan berbagai produk interaksi yang bertujuan untuk memfasilitasi kepentingan agen. Menurut Giddens (1984:2), obyek utama ilmu sosial bukanlah peran sosial seperti dalam fungsionalisme Parsons, bukan pula kode tersembunyi seperti terdapat dalam strukturalisme Levi-Strauss, atau bukan pula keunikan-situasional seperti dalam interaksionisme Goffman. Bukan keseluruhan, bukan bagian dan bukan pelaku-perorangan, melainkan titik temu keduanya, yaitu "praktik sosial yang berulang serta terpola dalam lintas ruang dan waktu."

Upaya-upaya pemaduan antara struktur dan agensi terus dilakukan. Ritzer (2012:888-930), misalnya, mengidentifikasi beberapa teoritisi yang karya-karyanya berusaha memadukan kesenjangan antara obyektivisme dan subyektivisme atau antara struktur dan tindakan agen (agensi), di antaranya Anthony Giddens dengan teori strukturasinya, Habermas yang mengusung teori tindakan komunikatif, dan Pierre Fellix Bourdieu dengan teori konstruktivisme-strukturalisnya. Pada umumnya teori-teori tersebut hadir dengan tujuan untuk melakukan sintesa peran agen dan struktur ke dalam relasi yang dialektik dalam membaca dan menganalisis struktur masyarakat, gejala sosial, dan perubahan sosial lainnya. Peran struktur obyektif dan tindakan subyektif 
Relasi Agen Dan Struktur: Ruang Negosiasi Dalam Pengelolaan Sumberdaya Hutan ......

agen menjadi perdebatan yang berkepanjangan diantara teoritisi sosial dalam menganalisis praktik-praktik sosial agen. Terkait dengan fenomena penelitian, maka pemikiran Anthony Giddens (2010) tentang strukturasinya dapat dijadikan sebagai dasar atau kerangka analisisnya.

Setidaknya, terdapat dua tema sentral yang kemudian dipandang oleh para ahli sosial sebagai poros gagasan orisinal Giddens, yaitu hubungan pelaku-struktur dan sentralitas ruang-waktu. Pertama, hubungan pelaku (agency) dan struktur (structure). Perbedaan antara pelaku dan struktur cukup jelas. Akan tetapi apakah perbedaannya itu berbentuk dualisme atau dualitas? Bagi Giddens, antara pelaku dan struktur adalah hubungan dualitas dan bukan dualisme. "Tindakan dan struktur selalu saling mengandaikan" (Giddens, 1979: 53). Apa yang disebut 'pelaku' adalah menunjuk pada orang konkrit dalam peristiwa-peristiwa yang terjadi. Struktur bukanlah nama bagi totalitas, bukan kode tersembunyi sebagaimana terdapat pada strukturalisme, dan bukan pula kerangka keterkaitan bagian-bagian dari suatu totalitas. Struktur ialah "aturan dan sumber daya yang terbentuk dari dan membentuk keterulangan praktik sosial”. Dualitas struktur-pelaku terletak dalam proses di mana "struktur sosial merupakan hasil dan sekaligus sarana praktik sosial (Priyono, 2000: 19). Struktur analog dengan langue (mengatasi ruang-waktu), sedang praktik sosial analog dengan parole (dalam ruangwaktu). Berdasar dualitas pelaku-struktur inilah, Giddens menggagas lahirnya Teori Strukturasi (Giddens, 2010).

Kedua, sentralitas ruang (space) dan waktu (time). Sebagai poros dari teori strukturasi, sentralitas ruang-waktu juga menjadi kritik pada dualisme statik-dinamik, sinkroni-diakroni. 'Waktu' dan 'ruang' bisanya dipahami sebagai arena (panggung) tindakan: kemana kita masuk, dari mana kita keluar. Diilhami oleh filsafat waktu Heidegger, Giddens (2010) menyatakan bahwa ruang-waktu bukanlah arena tindakan, melainkan unsur konstitutif dari tindakan dan pengorganisasian masyarakat. Atas dasar inilah, Giddens menamakan teorinya sebagai "strukturasi", sebagaimana setiap akhiran 'is (asi)' menunjuk proses ruang-waktu sebagai unsur konstitutif gejala sosial (Giddens, 2009: 337-446).

Tampaklah dengan jelas bahwa dalam teori strukturasi Giddens, kategori ruangwaktu menempati posisi yang sangat sentral. Strukturasi, proses bagaimana praktikpraktik sosial menjadi suatu struktur, memang hanya bisa terjadi dalam lintas ruang- 
waktu. Ada beberapa alasan yang dapat dikemukakan sehubungan dengan sentralnya kategori ruang-waktu dalam teori strukturasi Giddens (Gidens, 2009; 2010). Dalam teori-teori sosial yang ada persoalan ruang-waktu kurang diperhatikan secara serius. Ruang-waktu malah hanya dipandang sebagai "lingkungan" atau tempat ketika tindakan sosial dilakukan ataupun sebagai salah satu "faktor tidak tetap". Padahal menurut Giddens, ruang-waktu secara integral turut membentuk kegiatan sosial. Perbedaan bentuk-bentuk masyarakat, misalnya, tidak terletak pada cara-produksi sebagaimana yang menjadi keyakinan marxisme, melainkan dalam cara masing-masing masyarakat mengorganisasi hubungan antara ruang dan waktu (Giddens, 2009).

Menurut Giddens, salah satu hal yang seharusnya menjadi objek kajian ilmuilmu sosial adalah memandang hubungan pelaku ('tindakan') dan struktur sebagai hubungan dualitas dan bukannya dualisme. Dualitas ini menurut Giddens selalu terjadi pada praktik sosial yang berulang dalam lintasan ruang dan waktu (Gidens, 2010). Dimana letak dualitas pelaku-struktur dalam praktik sosial tersebut?

Dualitas itu terletak dalam fakta bahwa ia bisa dipandang sebagai "aturan" yang menjadi prinsip bagi tindakan di berbagai tempat dan waktu, sekaligus ia merupakan hasil dan sarana keterulangan tindakan kita yang karenanya mengatasi ruang dan waktu (Priyono, 2000: 19). Pengelaborasian relasi dualitas pelaku-struktur ini berbeda dengan pemahaman yang diberikan oleh Durkheim yang memandang struktur memiliki sifat mengekang (constraining), sedangkan dalam pemahaman Giddens struktur justru bersifat memberdayakan (enabling). Maksudnya, memungkinkan berlangsungnya praktik sosial. Itulah mengapa Giddens melihatnya sebagai 'sarana' (Piyono, 2000: 20).

Selanjutnya, Giddens (1979:82) menjelaskan bahwa prinsip-prinsip struktural itu terdiri dari tiga hal yang sangat mendasar, yaitu pertama, struktur 'signifikansi' (signification) yang berkaitan dengan dimensi simbolik, penyebutan dan wacana. Kedua, struktur 'dominasi' (domination) yang mencakup dimensi penguasaan atas orang (politik) dan barang (ekonomi). Ketiga, struktur 'legitimasi' (legitimation) menyangkut dimensi peraturan normatif yang terungkap dalam tata hukum.

Reproduksi sosial berlangsung melalui dualitas struktur dan praktik sosial. Persoalannya sekarang adalah apakah kita selaku para pelaku menyadari itu, ataukah kita hanya memiliki status sebagai pelaku seperti terdapat dalam fungsionalisme Parsons atau Marxisme Althuser? Jawaban Giddens terhadap persoalannya sangat jelas, 
Relasi Agen Dan Struktur: Ruang Negosiasi Dalam Pengelolaan Sumberdaya Hutan ......

bahwa menurutnya kita bisa tahu. Akan tetapi 'tahu' tidak harus diartikan 'sadar', apalagi dalam kapasitas menjelaskan semua proses secara eksplisit. Karenanya Giddens (1984:5) membedakan tiga dimensi internal pelaku : motivasi tidak sadar, kesadaran praktis, dan kesadaran diskursif.

Motivasi tak sadar (unconscious motivations) menyangkut keinginan atau kebutuhan yang berpotensi mengarahkan tindakan, tetapi bukanlah tindakan itu sendiri. Misalnya, sangat jarang seorang mahasiswa pasca ke kampus digerakkan oleh motif mencari gelar master. Kesadaran diskursif (discursive unconscious) mengacu pada kapasitas kita untuk merefleksikan dan memberi penjelasan eksplisit atas tindakan kita, misalnya, mengapa seorang mahasiswa pergi ke kampus (untuk kuliah)? Karena melaksanakan kewajiban (mencari ilmu). Sedangkan kesadaran praktis menunjuk pada gugus pengetahuan praktis yang selalu tak dapat diurai, misalnya, diam saat mengikuti acara perkuliahan. Menurut Giddens (2009), kesadaran praktis (practical unconscious) merupakan kunci untuk memahami strukturasi. Reproduksi sosial berlangsung melalui keterulangan praktik sosial yang jarang kita pertanyakan lagi.

Perbedaan tataran dalam dualitas struktur dan pelaku juga berguna untuk memahami istilah konflik (conflict) dan kontradiksi (contradiction). Konflik mengacu pada "pertikaian antara para pelaku atau kelompok dalam praktik sosial yang kongkrit" sedang istilah "kontradiksi" menunjuk "kondisi pertentangan prinsip-prinsip struktural pengorganisasian suatu masyarakat" pada tataran signifikansi, dominasi, dan legitimasi.

Ada dua pendekatan yang kontras bertentangan, dalam memandang realitas sosial. Pertama, pendekatan yang terlalu menekankan pada dominasi struktur dan kekuatan sosial (seperti, fungsionalisme parsonian dan strukturalisme, yang cenderung ke obyektivisme). Kedua, pendekatan yang terlalu menekankan pada individu (seperti, tradisi hermeneutik, yang cenderung ke subyektivisme). Menghadapi dua pendekatan yang kontras berseberangan tersebut, Giddens tidak memilih salah satu, tetapi merangkum keduanya lewat teori strukturasi. Melalui teori inilah Giddens (2010) menyatakan bahwa kehidupan sosial adalah lebih dari sekadar tindakan-tindakan individual. Namun, kehidupan sosial itu juga tidak semata-mata ditentukan oleh kekuatan-kekuatan sosial.

Struktur dan agensi tidak bisa dipahami secara terpisah. Pada tingkatan dasar, misalnya, orang menciptakan masyarakat, namun pada saat yang sama orang juga 
dikungkung dan dibatasi (constrained) oleh masyarakat. Struktur diciptakan, dipertahankan, dan diubah melalui tindakan-tindakan agen. Sedangkan tindakantindakan itu sendiri diberi bentuk yang bermakna (meaningful form) hanya melalui kerangka struktur. Jalur kausalitas ini berlangsung ke dua arah timbal-balik, sehingga tidak memungkinkan bagi kita untuk menentukan apa yang mengubah apa. Struktur dengan demikian memiliki sifat membatasi (constraining) sekaligus membuka kemungkinan (enabling) bagi tindakan agen.

Dalam strukturasi Giddens (Giddens, 2009; 2010), antara struktur dan tindakan merupakan dualitas dimana simbol-simbol, ide dan gagasan/keyakinan, nilai dan norma secara dinamis berproses dalam ruang dan waktu. Oleh karena itulah, dalam konsep dualitas, struktur tidak hanya menghambat dan menentukan bentuk-bentuk perilaku tertentu, tetapi juga memberikan kemampuan bagi perilaku; struktur memberikan kesempatan dan sekaligus hambatan.

Berdasarkan latar belakang tersebut, penelitian ini bertujuan untuk (1). Menganalisis bekerjanya struktur signifikansi, dominasi, dan legitimasi pola penguasaan dan pengelolaan sumberdaya alam berbasis; (2). Menganalisis bekerjanya struktur signifikansi, dominasi, dan legitimasi pola penguasaan dan pengelolaan sumberdaya hutan berbasis masyarakat lokal yang direpresentasikan melalui otoritas elite lokal; (3). Menganalisis pola bekerjanya kekuasaan negara dan otoritas elite lokal untuk mencapai konsensus dalam penguasaan dan pengelolaan sumberdaya hutan.

\section{METODE PENELITIAN}

Berdasarkan fenomena yang dikaji, penelitian ini menerapkan metode penelitian deskriptif-kualitatif yang menganalisis pola bekerjanya kekuasaan negara dan otoritas elite lokal dalam penguasaan dan pengelolaan sumberdaya hutan. Data dikumpulkan melalui teknik observasi nonpartisipasi, wawancara mendalam, dan dokumentasi. Observasi non partisipasi digunakan untuk mengumpulkan data dan informasi tentang perilaku masyarakat dalam pengelolaan sumberdaya hutan. Aspek yang diobservasi difokuskan pada praksis perilaku terkait dengan aturan, norma dan nilai, serta standar baku regulasi pengelolaan sumberdaya hutan pada tingkat individual, keluarga dan kelompok, maupun negara.Wawancara mendalam digunakan untuk menggali data yang terkait dengan aspek-aspek pengelolaan sumberdaya hutan oleh masyarakat dan negara, 
peran-peran tradisional dan kekuasaan elite lokal. Teknik dokumentasi digunakan untuk pengumpulan data sekunder (dokumen-dokumen penting), untuk menganalisis orientasi kebijakan pemerintah dibidang kehutanan selama hampir tiga dekade terakhir.

Data-data yang bersifat kualitatif dianalisis secara simultan bersamaan dengan proses pengumpulan data (on going analysis) dengan menggunakan analisis data yang berlaku dalam penelitian kualitatif. Proses analisis data dalam penelitian kualitatif meliputi pengujian, pemilahan, kategorisasi, evaluasi, membandingkan, melakukan sintesa dan merenungkan kembali data yang diperoleh untuk membangun inferensiinferensi teoritik, dan kemudian menarik kesimpulan (Neuman, 1997: 427).

Informan penelitian diperlukan untuk menjaring informasi yang dibutuhkan dalam penelitian kualitatif. Kelompok informan ini dipilih berdasarkan kebutuhan informasi di lokasi penelitian dan masalah penelitian yang akan dikaji. Beberapa informan yang dilibatkan dalm penelitian ini antara lain : tokoh formal dan informal desa seperti kepala desa dan perangkatnya, tokoh pemuda, dan ketua kelompok tani; elite lokal yang sedang berkuasa seperti kepala desa dan perangkatnya; Mantan Pasirah; Pemangku jabatan yang menentukan kebijakan perhutanan di daerah terutama dari dinas yang terkait dengan pengelolaan hutan seperti Dinas Kehutanan dan Lingkungan Hidup; dan ketua adat dan tokoh masyarakat.

Penelitian yang dilakukan mengambil lokasi di Desa Ladang Palembang, Kecamatan Lebong Utara, Kabupaten Lebong. Desa ini terletak di sekitar kawasan hutan lindung yang sejak lebih dari satu dasawarsa terakhir mengembangkan pola pengelolaan sumberdaya hutan berbasis masyarakat. Tumbuh dan berkembangnya kesadaran kolektif atas konservasi menjadi pertimbangan utama untuk menentukan desa tersebut sebagai lokasi penelitian.

\section{PEMBAHASAN}

Desa Ladang Palembang termasuk dalam wilayah Kecamatan Lebong Utara Kabupaten Lebong Provinsi Bengkulu. Desa ini terletak di kaki Bukit Barisan atau di bagian selatan kawasan Taman Nasional Kerinci Sebelat (TNKS)). Desa ini secara geografis memang menempati ruang yang berbatasan dengn TNKS sehingga ruang untuk aktivitas pertanian juga relatif terbatas. Luas wilayah desa ini $2.600 \mathrm{Ha}$ dengan penduduk sekitar 837 jiwa atau 227 kepala keluarga. Penggunaan lahan terutama untuk 
budidaya kopi, hortikultura, dan kebun campuran, serta lahan persawahan. Tekanan terhadap lahan semakin kuat seiring dengan pertambahan jumlah kepala keluarga yang membutuhkan areal untuk kegiatan produksi dan konsumsi.

Hal yang cukup menarik dari desa ini adalah adanya kesadaan kolektif komunitas lokal dalam konservasi sumberdaya hutan yang ada di lingkungannya. Kesadaran untuk melakukan konservasi hutan mandiri tersebut muncul dari pengalaman kemarau panjang sekitar 14 tahun lalu. Kesadaran tersebut pada awalnya muncul di kalangan elite desa, bahwa salah satu penyebab kekeringan tersebut adalah rusaknya sumberdaya hutan. Penggundulan hutan dapat menyebabkan kekeringan di musim kemarau dan kebanjiran serta longsor di musim penghujan. Dalam sebuah forum musyawarah desa, disepakati untuk menjaga dan melestarikan tiga kawasan hutan yang terletak di bagian atas desa, yakni hutan lindung Tik Gelung (15 Hektar), Hutan Lindung Bukit Sarang Macan (20 hektar), dan hutan adat Air Semiep (60 Hektar). Kesepakatan itu lalu dituangkan dalam peraturan desa yang juga mengatur sanksi bagi yang merusak ketiga kawasan hutan itu.

Inisiatif dan kesadaran kolektif komunitas lokal, salah satunya ditunjukkan dengan pengelolaan Perusahaan Air Minum (PAM) desa. Dibangunnya kesepakatan pengelolaan air minum desa ini sebagai "tangga" untuk pengelolaan hutan desa. Disepakati bahwa hutan merupakan sumber air yang menunjang keberlangsungan PAM desa. Dalam kaitan ini, pihak pemerintah desa dan elite-elitenya merumuskan kesepakatan dalam bentuk peraturan desa yang melarang siapapun merusak hutan. Peraturan Desa Nomor 05 tahun 2009, misalnya, mengatur pemanfaatan hasil hutan non-kayu tanpa merusak tanaman keras yang ada. Warga yang kebunnya berbatasan atau bahkan berada di dalam hutan adat wajib menjaga kebun dan hutan disekitarnya. Sanksi bagi mereka yang melanggar perdes sangat bervariasi. Orang yang menebang satu batang kayu, misalnya, dihukum memasak Serawo Punjung kambing (makanan khas Lebong), beras dua kaleng (32 kg), ditambah denda yang akan digunakan sebagai dana sosial. Sanksi dijatuhkan dalam sebuah sidang adat yang dihadiri seluruh warga. Di depan seluruh warga itulah, si pelanggar harus minta maaf atas perbuatannya, dan berjanji tidak akan mengulanginya. Seusai sidang, denda berupa makanan berikut beras yang sudah dimasak itu dihidangkan kepada warga layaknya kenduri. Peraturan itu juga mengatur mekanisme banding bagi pelanggar yang keberatan. 
Fenomena kesadaran kolektif masyarakat desa dalam pengelolaan sumberdaya hutan konservasi inilah yang menjadi fokus kajian dalam penelitian. Berawal dari asumsi bahwa tindakan kolektif tersebut bersumber dari insiatif dan prakarsa elite desa yang mampu melakukan relasi-relasi kekuasaan dengan pemerintah (baca: negara). Terdapat ruang-ruang negosiasi antara masyarakat yang diwakili oleh elite lokal dengan negara dalam pengelolaan sumberdaya hutan berbasis masyarakat.

\section{Negara dan Struktur Signifikansi, Dominasi Dan Legitimasi Atas Sumberdaya}

\section{Hutan}

Negara merupakan institusi tertinggi yang memiliki hak untuk menguasai dan mengelola sumberdaya hutan atas nama rakyat. Dalam praktiknya, kekuasaan tersebut dialihkan alasnya kepada pemerintah, dalam hal ini Kementerian Kehutanan melalui berbagai perundang-undangan dan peraturan. Produk hukum formal yang menunjang legitimasi pemerintah dalam pengelolaan sumberdaya hutan antara lain : UndangUndang No 5 Tahun 1967 tentang ketentuan-ketentuan pokok kehutanan Undangundang Nomor 5 Tahun 1990 tentang Konservasi Sumber Daya Alam Hayati dan Ekosistemnya; Undang-undang Nomor 24 Tahun 1992 tentang Penataan Ruang; Undang-undang Nomor 41 tahun 1999 tentang Kehutanan; Peraturan Pemerintah No. 28 Tahun 1985, tentang Perlindungan Hutan; Keputusan Presiden Nomor 32 Tahun 1990 tentang Pengelolaan Kawasan Lindung; Keputusan Presiden Nomor 34 Tahun 2002 tentang Tata Hutan Dan Penyusunan Rencana Pengelolaan Hutan, Pemanfaatan Hutan Dan Penggunaan Kawasan Hutan. Oleh karena itu, pemerintah merupakan simbol atau wacana kekuasaan atas sumberdaya hutan (dimensi signifikansi). Karena kepemilikan kekuasaan tersebut, maka hanya pemerintah yang memiliki hak untuk mengalokasikan dan menguasai sumberdaya hutan (dimensi dominasi). Pemerintah melalui perundangundangan dan peraturan yang ada telah memiliki aturan normatif formal sebagai satusatunya institusi yang berhak menguasai dan mengelola sumberdaya hutan (dimensi legitimasi).

Dalam Undang-Undang Pokok Agraria (UUPA) Tahun 1960, misalnya, negara memiliki hak menguasai sumberdaya alam, termasuk hutan sebagai perwujudan pelimpahan tugas dari hak bangsa (hak seluruh rakyat Indonesia) yang sifatnya abadi. Hak bangsa ini memiliki dua unsur utama, yakni unsur kepunyaan dan unsur tugas kewenangan untuk mengatur dan memimpin penguasaan dan penggunaan sumberdaya 
alam secara bersama-sama. Hak menguasai ini, oleh karenanya, tidak bisa dipindahkan ke pihak lain, tetapi landasan hak sumberdaya alam yang dikuasai negara dapat saja dialihkan kepada pihak lain, dalam hal ini swasta atau Badan Usaha Milik Negara (BUMN). Negara yang telah diberikan wacana kekuasaan dalam pengelolaan sumberdaya alam, termasuk hutan, mengalihkan alas haknya kepada pemerintah sebagai penjelmaan kekuasaan negara untuk menguasai dan mengelola sumberdaya alam. Dengan kata lain, pemerintah telah memperoleh signifikansi, yakni simbol atau wacana kekuasaan atas sumberdaya hutan. Di lokasi penelitian, simbol kekuasaan tersebut ditunjukkan dengan penerapan kawasan hutan lindung, taman nasional, dan cagar alam dengan tujuan untuk pencapaian pencegahan, perlidungan dan pelestarian hutan. Dengan kata lain, hutan konservasi tersebut merupakan simbol atau wacana kekuasaan pemerintah atas sumberdaya yang ada.

Pengalihan hak atas pengelolaan sumberdaya hutan dari negara menampakkan dampaknya pada simbol atau wacana kekuasaan pemerintah. Departemen Kehutanan dan Lingkungan Hidup atau Dinas Kehutanan provinsi merupakan refleksi dari simbol kekuasaan negara atas sumberdaya hutan. Dengan kata lain, hanya pemerintah yang memiliki hak untuk mengalokasikan dan menguasai sumberdaya hutan dengan segala atribut yang melekat di dalamnya. Dalam pandangan Giddens, pemerintah memiliki konsekuensi unsur dominasi penguasaan sumberdaya hutan. Tidak jarang dengan atribut dominasi tersebut, pemerintah selama lebih dari tiga dekade menguasai sumberdaya hutan dengan segala kebijakan yang justru memarjinalkan hak menguasasi masyarakat atas sumberdaya yang tersedia di lingkungannya. Selain itu, tindakan represif seperti pengusiran, pembakaran pondok-pondok kebun warga, penangkapan, dan bentukbentuk tindakan penekanan lain mewarnai kebijakan pengamanan dan perlindungan hutan. Penyebutan masyarakat sekitar hutan sebagai perambah hutan liar, peladang liar, pencuri kayu liar, dan sebutan "liar" lainnya menjadi alasan pembenar bagi pemerintah untuk melakukan tindakan represifnya, dan harus ditindak tegas secara hukum.

Kriminalisasi tindakan masyarakat seperti itu sebagai bentuk dari budaya kontrol yang diciptakan negara untuk melindungi dan mengamankan sumberdaya hutan, atau ekspresi sebuah kultur penguasaan dan pengelolaan hutan berbasis negara. Sangat umum dilihat bahwa pendekatan hukum yang digunakan pemerintah untuk mengontrol dan mengamankan aset senantiasa ditunjukkan oleh dominasi negara atas masyarakat 
dalam bentuk pembuatan aturan yang mengedepankan keamanan, mengutamakan aparat dalam melaksanakan operasional di lapangan, menonjolkan berbagai bentuk ancaman dan sanksi, dan menggusur hak-hak dan akses masyarakat lokal terhadap sumberdaya hutan. Tidak mengherankan apabila stigma serba "liar" yang dialamatkan kepada masyarakat sekitar kawasan hutan menjadi sebuah kebiasaan yang dianggap paling mudah untuk melakukan penekanan atas nama legitimasi. Menurut tuturan masyarakat lokal, kekuasaan negara atas sumberdaya hutan memang sangatlah dominan sehingga masyarakat lokal terpaksa untuk tidak memasuki wilayah hutan yang selama beratus tahun telah menjadi area aktivitas pertanian secara turun temurun.

Pengelolaan sumberdaya hutan yang berbasis negara cenderung bersifat sentralistik. Ciri-ciri umum penguasaan dan pengelolaan hutan yang berbasis negara ditandai oleh perilaku yang cenderung mengatur dan mengendalikan, orientasi keuntungan jangka pendek, perencanaan kehutanan yang bersifat kaku, pengambilan keputusan yang bersifat unilateral, dan sumberdaya hutan dieksploitasi semata-mata untuk sumber pendapatan dan devisa negara. Mandat penguasaan dari negara dijewantahkan ke dalam bentuk hukum-hukum formal sebagai landasan operasionalnya.

Ketika wacana atau simbol kekuasaan pemerintah atas sumberdaya hutan sudah diberikan (signifikansi), dan kemudian pemerintah menjadi satu-satunya agen yang memiliki hak untuk mengalokasikan dan menguasai sumberdaya hutan (dominasi), maka pengejawantahan kekuasaan tersebut diwujudkan dalam bentuk keberlakuan hukum formal (legitimasi). Melalui pembuatan undang-undang dan berbagai peraturan sebagai ikutannya, maka pemerintah memiliki aturan normatif formal sebagai satusatunya institusi yang berhak menguasai dan mengelola sumberdaya hutan. Dengan kata lain, pemerintah telah memperoleh legitimasinya melalui beragam produk hukum formal.

Kekuasaan negara atas sumberdaya hutan diwujudkan dalam bentuk produk hukum dan kebijakan yang mengarah pada dua kepentingan: Pertama, kebijakan pemanfaatan sumberdaya hutan untuk tujuan-tujuan kemakmuran rakyat sebesarbesarnya. Dengan kata lain, terdapat komersialisasi kawasan hutan produksi untuk perolehan devisa negara. Kedua, kebijakan pengamanan kawasan hutan dari gangguan pihak lain (baca: masyarakat) sekitar hutan demi pertimbangan konservasi dan pelestarian keragaman hayati. Kebijakan inilah yang sering menjadi alasan operasional 
pencegahan terhadap masyarakat sekitar hutan untuk tidak masuk kawasan hutan. Pada tataran empirik, pembatasan kawasan hutan lindung, taman nasional, dan cagar alam untuk dimasuki masyarakat merupakan bentuk dari kebijakan pengamanan dan pelestarian kawasan hutan.

Argumentasi beragamnya kebijakan pengelolaan sumberdaya hutan dan konsekuensi yang ditimbulkannya menunjukkan fenomena bekerjanya kekuasaan negara atas sumberdaya hutan. Secara umum kategori kepemilikan dan pengelolaan hutan terdiri dari empat komponen paling mendasar. (1). Common pool resources yang acapkali ditandai oleh kebebasan untuk memanfaatkan dan mengolah sumberdaya; (2). Common property yang dicirikan oleh keteraturan dalam pemilikan dan pengelolaan sumberdaya hutan. Pada komponen ini, pengelolaan sumberdaya hutan dijembatani oleh aturan, norma, dan pranata kolektif dalam memanfaatkan sumberdaya hutan; (3). State property sebagai output dari sebuah proses legislasi kebijakan formal yang menyebabkan terjadinya pengalihan alas hak atas hutan dari negara ke pemerintah. Kawasn-kawasan taman nasional, hutan lindung, hutan kawasan produksi terbatas, merupakan contoh-contoh kawasan hutan yang dikuasai oleh negara sebagi produk hukum formal; (4). Private property, yakni sebuah proses pengalihan alas hak atas hutan dari state property right menjadi private property right. Kawasan hutan yang dikuasai oleh negara kemudian dialihkan pengelolaannya kepada swasta dan atau Badan Usaha Milik Negara (BUMN). Oleh karena itu, pihak-pihak yang diberikan pelimpahan kewenangan tersebut memiliki hak pengelolaan sumberdaya hutan dengan segala konsekuensinya.

Berdasarkan kategori penguasaan sumberdaya hutan tersebut, konflik kerapkali terjadi antara kawasan yang dikuasai negara dan kawasan yang dikuasai oleh swasta. Konflik umumnya lebih disebabkan oleh keyakinan masyarakat sekitar hutan yang merasa akses terhadap sumberdaya hutan "tercerabut" oleh kebijakan negara dan atau swasta. Namun demikian, beberapa program dari pemerintah berusaha untuk meminimalkan konflik melalui kebijakan-kebijakan pengelolaan hutan berbasis masyarakat atau lebih dikenal dengan social forestry, atau redistribusi kawasan hutan kepada masyarakat adat seperti program-program sertifikasi lahan yang selama ini menjadi sumber konflik antara negara dan masyarakat. 
Disadari ataupun tidak, bekerjanya kekuasaan dalam praktek pengelolaan hutan akan melahirkan relasi-relasi kekuasaan antara pemerintah, masyarakat, dan pengusaha yang memperoleh konsesi kawasan hutan. Relasi kekuasaan tersebut berada pada kondisi timpang, yakni satu pihak (baca: pemerintah dan pengusaha) memiliki kekuasaan yang lebih atas sumberdaya hutan berdasarkan mandat negara yang ditopang oleh yuridis formal. Sementara, pihak yang dikuasai (baca: masyarakat sekitar hutan) cenderung memiliki posisi tawar yang lemah. Dalam kondisi ini, pemerintah memiliki kemampuan untuk mengendalikan, mempengaruhi, dan mengakibatkan masyarakat melakukan sesuatu tindakan sesuai aturan formal. Sebaliknya, masyarakat juga dimungkinkan memiliki kemampuan untuk mengendalikan, mempengaruhi, dan bahkan menyebabkan pemerintah melakukan sesuatu tindakan dalam pengelolaan sumberdaya hutan, apabila kekuasaan masyarakat didasarkan pada aturan dan hukum adat yang berlaku. Dalam posisi yang demikian, akan terbangun relasi-relasi kekuasaan di antara kedua belah pihak dan atau muncul konflik konflik penguasaan sumberdaya hutan.

\section{Elite Lokal dan Struktur Signifikansi, Dominasi, dan Legitimasi Atas Hutan}

Masyarakat lokal yang umumnya bermukim di sekitar kawasan hutan konservasi merupakan stereotype komunitas peladang dan pekebun yang memang "haus" akan luasan lahan untuk aktivitas pertaniannya. Secara historis, mereka melaksanakan prinsip-prinsip perkebunan dan perladangan berdasarkan pada bentuk-bentuk kearifan lokal yang telah terendapkan dalam jangka waktu yang lama. Di setiap komunitas apapun, bentuk-bentuk kearifan lokal tersebut cenderung menjadi bagian dari sistem pengelolaan lingkungan dan sumberdaya alam (Tjahjono et al., 1999, Suminar et al., 2004). Praktik-praktik pengelolaan sumberdaya alam dan lingkungan, dengan demikian, merupakan produk dari pengetahuan keseharian yang diperkuat oleh pengalaman individu dalam dunia sosialnya. Dengan demikian, bentuk-bentuk kearifan tersebut diproduksi dan direproduksi dari generasi ke generasi melalui interaksi dengan lingkungannya, baik lingkungan fisik maupun lingkungan sosial. Giddens (2009:180) meyakini bahwa reproduksi sosial dapat terjadi: (1). Dalam jaringan interaksi langsung, seperti dicapai atau dihadirkan oleh para pelaku, yakni reproduksi dalam pengertian yang paling mendasar; (2). Dalam reproduksi anggota sistem sosial sebagai mahluk dengan rentang waktu yang terbatas, yang tentunya ditanamkan ke dalam reproduksi 
biologis; (3). Dalam reproduksi institusi yang diendapkan dalam durasi panjang secara historis.

Melalui konstruksi sosial atas bentuk-bentuk kearifan tersebut, masyarakat lokal telah menumbuhkembangkan pola-pola institusi atau kelembagaan pengelolaan sumberdaya hutan. Oleh karena itu, muncul sistem marga dengan segala atribut kekuasaan dan kewenangannya dalam menata kehidupan kemasyarakatan. Sistem ini telah banyak melahirkan elite-elite desa yang memiliki pengaruh kuat dalam pengambilan keputusan terkait dengan alokasi sumberdaya yang dimiliki marga, termasuk kawasan hutan. Sebelum diberlakukannya Undang-Undang Nomor 5 Tahun 1979, unit-unit pemerintahan di daerah masih mengacu pada sistem kemargaan, yakni kesatuan masyarakat adat yang memiliki perbedaan dengan konsepsi marga seperti di suku-suku lainnya. Kesatuan masyarakat adat tersebut biasanya memiliki sumberdaya untuk menunjang aktivitas anggota marga, salah satunya sumberdaya hutan, yang sering disebut dengan hutan marga. Tetapi ketika Undang-Undang Nomor 5 Tahun 1979 diterapkan, maka kesatuan masyarakat yang paling kecil diubah menjadi desa. Dengan demikian, kesatuan masyarakat adat secara otomatis tidak berlaku lagi, meskipun di beberapa wilayah masih tetap untuk dipertahankan secara simbolis.

Sementara itu, simbol atau wacana kekuasaan elite desa atas sumberdaya hutan dimanifestasikan ke dalam bentuk pelimpahan kewenangan untuk mengawasi sumberdaya yang ada di desa. Seringkali atribut kekuasaan informal di desa melekat pada elite-elite desa yang diberikan kewenangan untuk pengaturan kemasyarakatan dan distribusi sumberdaya yang ada. Semua individu dan kelompok mengakui simbol kekuasaan elite tradisional yang setiap keputusannya memiliki kekuatan hukum informal. Elite-elite tersebut, dengan demikian, memiliki dimensi signifikansi.

Dengan atribut simbol atau wacana kekuasaan yang melekat pada elite desa, maka konsekuensinya hanya elite desa yang memiliki hak untuk mengalokasikan dan menguasai sumberdaya hutan (dominasi). Para elite ini memiliki mobilitas vertikal yang lebih baik dibandingkan dengan kebanyakan orang. Kemampuan elite desa untuk berinteraksi dengan individu dan atau organisasi di luar desanya menjadikan masyarakat lokal semakin menyakini atas atribut kekuasaan yang melekat padanya. Di Desa Ladang Palembang, misalnya, para elite desa berhasil membangun komunikasi dan berinteraksi dengan pihak luar desa, baik individu maupun lembaga. Mereka menjalin relasi dengan 
perguruan tinggi, lembaga swadaya masyarakat, bahkan tokoh-tokoh eksternal yang memungkinkan dapat membuka akses sumberdaya di luar desanya. Elite-elite desa berusaha untuk mendapatkan dukungan atas atribut signifikansi yang melekat melalui pola-pola interaksi eksternal sehingga memperoleh legitimasi untuk melaksanakan dominasinya dalam pengelolaan sumberdaya hutan.

Ketika atribut kekuasaan sudah dimiliki, dan hak atas distribusi sumberdaya desa digenggamnya, maka elite desa harus mampu memperoleh legitimasi yang kuat di mata masyarakat lokal dan atau pihak luar. Legitimasi informal sudah diperoleh dari masyarakat, dan hal ini akan terus bertambah seiring dengan kemampuan elite untuk melakukan interaksi dengan pihak lain yang akan membawa kemajuan di desa. Elite desa baik formal maupun informal dapat melaksanakan fungsi-fungsi signifikansi, dominasi, dan legitimasi apabila dibarengi dengan mandat formal dari segenap komponen di desa.

Dalam kasus di Desa Ladang Palembang, struktur signifikansi, dominasi, dan legitimasi elite lokal atas sumberdaya hutan dijewantahkan ke dalam bentuk kesepakatan-kesepakatan formal desa yang orientasinya pada upaya mewujudkan pola pengelolaan hutan konservasi berbasis masyarakat. Elite formal dan informal lokal memainkan peranannya berdasarkan atribut kewenangan dan legitimasi yang diberikan warga. Kerapkali negosiasi yang dilakukan oleh elite desa dengan pihak-pihak yang berkepentingan dengan hutan dilakukan melalui dua dimensi simbol kekuasaan dan legitimasi. Di hadapan pihak-pihak eksternal, elite desa melakukan konsensus atas nama masyarakat desa, dan segala hasil yang dicapai melalui negosiasi tersebut menjadi tanggung jawabnya. Namun ketika elite desa berhadapan dengan masyarakat, mereka berperan sebagai representasi negara yang telah diberikan wewenang dan kekuasaan mengelola sumberdaya hutan di desa. Dua "kemasan" peran elite desa ini sebenarnya merupakan bekerjanya struktur signifikansi, dominasi, dan legitimasi dalam bentuk yang lain.

\section{Relasi antara Negara dan Otoritas Elite Lokal: Menguak Ruang Negosiasi}

Dalam teori strukturasi, terdapat dua unsur utama yang memainkan peran sangat penting. Unsur pertama, agen sebagai “subyek yang berpengetahuan dan cakap". Agen tahu apa yang ia lakukan dan mengapa ia melakukannya. Menurut Giddens, semua tindakan adalah "bertujuan" (Giddens: 1979: 56). Penekanan bahwa agen adalah 
berpengetahuan dan tindakan mereka mengandung maksud dan tujuan adalah salah satu dari dasar pemikiran Giddens. Negara, dalam hal ini, dapat disebut agen yang melakukan keputusan-keputusan penting terkait dengan kebijakan pengelolaan sumberdaya hutan. Keputusan-keputusan tersebut berupa pelimpahan wewenang penguasaan dan pengelolaan hutan kepada pemerintah. Dengan demikian, pemerintah menjadi agen yang merepresentasikan negara yang harus membuat keputusan-keputusan pengelolaan sumberdaya hutan yang sudah menjadi kewenangan dan kekuasaannya.

Berkenaan dengan proses pembuatan keputusan, menurut Giddens, "pelaku mungkin mengkalkulasi resiko-resiko yang tercakup dalam melakukan tindakan sosial tertentu, berkaitan dengan kemungkinan sangsi-sangsi atau yang sebenarnya diterapkan, dan ia mungkin siap tunduk kepadanya sebagai harga yang mesti dibayar untuk mendapatkan tujuan tertentu" (Giddens, 1979: 87). Dalam teori ini, orang menggunakan analisis biaya-keuntungan (cost-benefit analysis) agar bisa membuat sebuah keputusan. Jika keuntungan untuk melakukan suatu tindakan lebih besar daripada biaya-biayanya, maka tindakan tersebut akan dilakukan. Biaya di sini mencakup kemungkinan mengalami atau terkena sanksi-sanksi yang negatif. Jika keuntungan dari sebuah tindakan tersebut sama baik dari segi biaya-biaya dan sangsi-sangsinya, maka perbuatan itu dilakukan.

Ketika masyarakat di Desa Ladang Palembang membuat keputusan untuk melakukan konservasi hutan, maka pertimbangan kerugian yang selama ini dirasakan sebagai akibat dari penggundulan hutan menjadi dasar utamanya. Keputusan untuk mengkonservasi hutan di tiga wilayah hutan desa, tentunya diperoleh melalui berbagai pertimbangan untung dan ruginya. Menjadi persoalan, siapa yang menginisiasi untuk pengambilan keputusan tersebut? Dari hasil kajian, nampak bahwa elite desa yang memiliki jaringan dan pengetahuan cakap mengawali ide-ide untuk melakukan konservasi hutan desa. Dalam hal ini, elite desa kemudian diberikan otoritas untuk melakukan segala tindakan yang diperlukan dalam rangka melaksanakan kesepakatan bersama. Dalam perspektif strukturasi, elite desa tersebut berperan sebagai agen yang melakukan interaksi dengan individu dan atau kelompok lain, baik di dalam desa maupun di luar desa. Elite desa tersebut dianggap sebagai pelaku yang memiliki "pengetahuan yang sempurna" tentang manfaat konservasi hutan. 
Relasi Agen Dan Struktur: Ruang Negosiasi Dalam Pengelolaan Sumberdaya Hutan ......

Unsur kedua dalam teori strukturasi adalah peran struktur dalam perubahan sosial, termasuk dalam pengelolaan sumberdaya hutan desa. Giddens mendefinisikan struktur sebagai “aturan-aturan dan sumber-sumber yang dilibatkan secara berulangulang (recursive) dalam reproduksi sistem-sistem sosial. Struktur hanya ada dalam jejak-jejak memori, dasar organis bagi kemampuan mengetahui dari manusia, dan seperti dikongkritkan dalam tindakan" (Giddens, 1984: 377). Dengan kata lain, struktur mencakup aturan-aturan (rules) yang mengatur masyarakat. Penggunaan istilah recursive menunjuk kepada suatu pengertian bahwa struktur bisa menjadi media dan sekaligus hasil dari praktik-praktik sosial yang membentuk sistem-sistem sosial. Ini menyiratkan bahwa struktur dipengaruhi dan sekaligus mempengaruhi perubahan sosial. Jadi, struktur pada intinya bersifat recursive (berulang).

Dalam rangka mensuksesakan program konservasi hutan desa, maka elite desa dengan kesepakatan bersama merumuskan berbagai aturan desa dalam bentuk peraturan desa tentang sistem konservasi hutan desa tersebut. Peraturan ini disepakati dan dijalankan bersama sehingga menghasilkan praktik-praktik sosial konservasi hutan desa, yang pada gilirannya mereproduksi struktur sosial desa. Giddens memandang struktur sosial sebagai ciri-ciri yang tidak dapat diraba. Seorang tidak bisa memandang aturanaturan atau sumber-sumber sebuah masyarakat dengan sendirinya, hanya pengaruhpengaruhnya saja yang bisa dipelajari. Jadi, struktur ada hanya secara instan. Karena struktur dilibatkan dalam perubahan sosial, maka keberadaannya sebagai entitas yang bisa diraba (dapat diukur) hanya bersifat temprorer. Dengan kata lain, struktur tidak pernah statis, ia selalu dimodifikasi.

Relasi-relasi dan interaksi antara elite lokal dengan negara memiliki makna interpretasi yang berbeda. Bagi elite desa, otoritas yang diberikan oleh masyarakat lokal memberikan kesempatan untuk melakukan interaksi dengan beberapa pihak di luar desa. Elite desa, dapat berupa kepala desa ataupun tokoh masyarakat, merepresentasikan otoritas masyarakat untuk melakukan negosiasi dengan pemerintah atas nama negara. Konsensus-konsensus yang disepakati antara elite desa dengan pemerintah dan atau pihak lain merupakan proses signifikansi atau pemaknaan terhadap program konservasi hutan di Desa Ladang Palembang. Sebaliknya, pemerintah atas nama negara memberikan pemaknaan terhadap program konservasi desa dengan pijakan pada aturanaturan yang telah ditetapkan oleh negara. Masyarakat lokal tetap berpijak pada aturan 
yang telah disepakati oleh masyarakat terkait dengan program-program konservasi hutan desa.

Perbedaan pemaknaan tersebut seringkali menimbulkan prasangka sosial di antara kedua belah pihak, kecuali dapat diperoleh kesepakatan dalam relasi-relasi kekuasaan di antara kedua agen tersebut. Dalam kondisi seperti inilah, elite desa melakukan negosiasi dengan pemerintah dan atau pihak lain untuk memperoleh sumberdaya yang dibutuhkan dalam rangka praktik sosial pengelolaan sumberdaya hutan desa. Elite desa memainkan otoritas masyarakat desa untuk melakukan negosiasi dan kesepakatan dengan pihak lain. Sementara pemerintah melalui instansi terkait melakukan negosiasi atas nama otoritas negara.

Kekuasaan negara atas sumberdaya hutan pada hakikatnya didukung oleh sumberdaya hukum, politik, dan finansial yang sangat kuat sehingga negara mampu mendominasi masyarakat yang bermukim di sekitar kawasan hutan. Relasi-relasi kekuasaan yang dibangun negara senantiasa berdimensi pada dominasi terhadap masyarakat lokal sehingga pada gilirannya terdapat dua kelas yang didominasi (baca: masyarakat lokal) dan yang mendominasi (baca: negara). Namun demikian, masyarakat lokal dengan kekuatannya sendiri juga memiliki kekuasaan yang basisnya adalah kesepakatan masyarakat terkait dengan pola-pola pengelolaan sumberdaya hutan.

Fenomena menarik adalah elite Desa Ladang Palembang dengan legitimasi dan kekuasaan yang ada didukung dengan sumberdaya yang dimiliki mampu melakukan relasi-relasi kekuasaan dengan negara dan atau pihak lain atas nama masyarakat. Legitimasi tersebut diperoleh elite desa melalui aturan dan norma serta sanksi yang telah disepakati bersama. Legitimasi yang melekat dalam elite desa maupun pemerintah atas nama negara menimbulkan relasi-relasi yang khas dan sering berubah-ubah.

Dalam dimensi waktu dan tempat seperti yang diutarakan oleh Giddens, maka relasi-relasi kekuasaan tersebut seringkali berubah-ubah disesuaikan dengan tempat dan waktu. Ketika elite desa harus melakukan interaksi dan relasi-relasi dengan pemerintah dan atau pihak lain, maka terdapat kecenderungan perubahan-perubahan orientasi hasil dari relasi tersebut. Pada saat tertentu, elite desa mengatasnamakan masyarakat di depan negara, tapi dalam kurun waktu yang lain mereka melakukan relasi dengan masyarakat atas nama negara. Perubahan-perubahan tersebut dasar yang paling fundamental adalah kepentingan yang selalu berubah-ubah berdasarkan tempat dan waktu. 
Relasi Agen Dan Struktur: Ruang Negosiasi Dalam Pengelolaan Sumberdaya Hutan ......

Ketika negara memiliki kepentingan untuk melakukan negosiasi dengan elite desa, maka aparat mengatasnamakan kepentingan masyarakat melakukan tindakantindakan sosial yang ditujukan untuk menghindarkan kemacetan dalam relasi-relasi kekuasaan yang dibangun. Kepentingan ini antara lain implementasi program-program pemerintah yang membutuhkan partisipasi masyarakat lokal. Tapi di lain waktu, negara akan melakukan dominasi kekuasaannya atas sumberdaya hutan atas nama legitimasi yuridis formal.

\section{KESIMPULAN}

Struktur signifikansi, dominasi, dan legitimasi negara atas pengelolaan sumberdaya hutan berbasis negara memiliki kecenderungan untuk berubah-ubah sesuai dengan kepentingan yang akan dicapai. Sumberdaya hutan bagi negara adalah sumberdaya publik dan diinterpretasikan sebagai sumberdaya yang harus dilindungi. Dasar perlindungan tersebut berupa undang-undang dan berbagai peraturan yang mengikutinya. Legitimasi ini pada gilirannya menumbuhkan relasi-relasi kekuasaan yang cenderung bersifat dominasi atas masyarakat lokal.

Struktur signifikansi, dominasi, dan legitimasi masyarakat lokal atas pengelolaan sumberdaya hutan berbasis masyarakat berkecenderungan dilakukan melalui elite-elite desa yang mampu melakukan relasi dan interaksi dengan pihak lain. Elite desa dengan legitimasi yang diperoleh dari masyarakat pada tataran tertentu melahirkan dominasi kekuasaan terhadap masyarakat lokal. Relasi-relasi kekuasaan dengan negara dilakukan berdasarkan kepentingan yang harus dicapai, baik untuk kepentingan individu maupun kepentingan masyarakat yang diwakilinya.

Interaksi dan relasi yang dibangun pada dasarnya dipengaruhi oleh kepentingan dan posisi dalam dimensi waktu dan tempat. Hambatan-hambatan struktural dalam praktik-praktik sosial pengelolaan hutan berbasis negara dan berbasis masyarakat dapat direduksi melalui relasi-relasi kekuasaan antara agen (baca: elite lokal dan pemerintah) yang berubah-ubah dalam perolehan konsensus dan kesepakatan atas kepentingankepentingan yang harus dicapai. Perubahan ruang dan waktu inilah yang dapat memunculkan "terkuaknya" ruang-ruang negosiasi baru antar negara dan elite lokal untuk meminimalkan konflik kepentingan, nilai, ide dan gagasan dalam pengelolaan sumbedaya hutan. 
Dalam rangka konservasi sumberdaya hutan, pendekatan formal yang sifatnya memaksa relatif tidak mampu menumbuhkembangkan inisiatif dan kreativitas masyarakat lokal. Oleh karena itu, memberikan kesempatan kepada masyarakat lokal untuk mengelola sumberdaya alamnya secara mandiri memiliki dampak pada pengelolaan sumberdaya hutan yang berkesinambungan.

\section{DAFTAR PUSTAKA}

Giddens, Anthony, 1979. Central Problem in Social Theory, London: Macmillan.Problematika Utama dalam Teori Sosial; Aksi, Struktur,dan Kontradiksi dalam Analisis Sosial. Terjemahan oleh Dariyatno. 2009. Yogyakarta:Pustaka Pelajar.

-1984. The Constitution of Society, Cambridge: Polity Press.Teori Strukturasi Dasar-Dasar Pembentukan StrukturSosial Masyarakat. Terjemahan oleh Maufur dan Daryanto. 2010.Yogyakarta:Pustaka Pelajar.

---------.2009. Problematika Utama dalam Teori Sosial: Aksi, Struktur, dan Kontradiksi dalam Analisis Sosial. Terjemahan Dariyatno. Yogyakarta: Pustaka Pelajar.

-2010. Teori Strukturasi: Dasar-Dasar Pembentukan Struktur Sosial Masyarakat. Terjemahan Maufur dan Dariyatno. Yogyakarta: Pustaka Pelajar. Hardin, Garret. (1968). The Tragedy of the Commons. Science, 162(1968):12431248 [Online]: http://dieoff.org/page95.htm. Diakses 11 Nopember 2010, 11.36 AM.

Neuman, W. Lawrence, 1997. Social Research Methods. Qualitative and Quantitative Approaches. Boston: Allyn and Bacon.

Peluso, Nancy, Lee.1995. Whose Woods are these? Counter-mapping in the forests of West Kalimantan, Indonesia. Antipode. No. 27 (4): 383-406.

Peluso, Nancy Lee.2006. Hutan Kaya, Rakyat Melarat: Penguasaan Sumberdaya dan Perlawanan di Jawa. Jakarta: Konphalindo.

Priyono, B. Herry. 2000. “Sebuah Terobosan Teoritis” dalam Majalah Basis, no. 0102, tahun ke-49, Januari-Pebruari.

Ritzer, George.2012. Teori Sosiologi: Dari Sosiologi Klasik Sampai Perkembangan terakhir Postmodern. Yogyakarta: Pustaka pelajar

Suminar, Panji; P.E. Tjahjono, Herawan S. 2004. Pengembangan Model Solusi Konflik Hutan Konservasi di Tiga Komunitas Bengkulu. Jakarta: Kantor Kementerian Riset dan Teknologi dan Lembaga Ilmu Pengetahuan Indonesia. 
76 I Panji Suminar

Relasi Agen Dan Struktur: Ruang Negosiasi Dalam Pengelolaan Sumberdaya Hutan ......

Tangketasik, Jansen,.2010. Antara Negara dan Tongkonan: Ruang-Ruang Negosiasi Baru dalam Penguasaan Sumberdaya Hutan di Kabupaten Tana Toraja, Sulawesi Selatan. Disertasi. Jakarta: Universitas Indonesia.

Tjahjono, Purwadi Eka; P. Suminar; K. Hakim; A. Aminudin.1999. Pola Pelestarian Keanekaragaman hayati Berdasarkan Kearifan Lokal Masyarakat Sekitar Kawasan Taman Nasional Kerinci Seblat di Provinsi Bengkulu. Jakarta: Yayasan Kehati. 